\title{
ERICH KÄSTNER - ATIVIDADE LITERÁRIA EM PROL DO NEO-OBJETIVISMO E NEO-HUMANISMO
}

Reinaldo Bossmann

Da Universidade do Paraná

As atividades de Kästner começaram no ano de 1923 , quando, ainda estudante, resolveu ser jornalista e redator. Suas primeiras poesias e artigos apareceram em diversas revistas e jornais com o seu nome ou sob o pseudônimo de Peter Flint. Logo se tornou colaborador das conhecidas revistas "Die Weltbühne" e "Simplizissimus". Sua singular carreira literária pôde ser acrescida com a mudança para Berlim: "Assim, eu embarquei, em 1927, sem dinheiro, para conquistar Berlim." No mesmo ano publicou seu primeir volume de poesias "Herz auf Taille" (Coração na cintura). Seguiram "Lärm im Spiegel" (Barulho no espelho), "Ein Mann gibt Auskunft" (Um homem dá informações), "Gesang zwischen den Stühlen" (Canto entre as cadeiras). Tais poesias obtiveram grande sucesso. Em poucos anos foram vendidos mais de 10.000 exemplares. O estranho título das coleçōes, o novo mundo realístico de expressão dessas estrofes atuais, o tom satírico, decadente e melancólico, entusiasmaram os leitores, especialmente nas cidades, onde o cetecismo dominava, aí pelos finś da terceira década. A linguagem diária e acertada nos versos, o sentido claro, as visões reais, a seqüência, hàbilmente coordenada, dos temas, os metros, a seriedade e humor, cinismo e ingenuidade, mostram Kästner não só como um lírico razoável, mas também como um grande propagandista, pois; nos primeiros anos berlinenses, Kästner trabalhou também como propagandista, fazendo singular propaganda de cigarros inferiores. Afinal, como poeta e escritor, 
Kästner permaneceu sempre como propagandista; mas êle oferece agora uma mercadoria melhor e mais substanciosa: a humanidade, o amor ao próximo, a tolerância, a honestidade, a insignificância individual e o humor sadio. E' característico de Kästner que o mesmo tivesse começado a carreira literária como poeta, mas alcançou renome como prosador, fama mundial como escritor de livros infantis, como escritor puro. Com isso, realizou-se em Kästner uma sentença, com preâmbulo contrário, de Theodor Däubler: "Um escritor que nunca escreveu um poema, não é um escritor!" Kästner toma parecer da opinião de Däubler: "Esta afirmação, aliás, não é certa. Ela não coincide, mas, ela é verdadeira."

Os quatro volumes de lírica, poemas que nos anos de 1930 foram considerados e imitados, representaram o tipo da lírica contemporânea porque corporificam o hálito, a mentalidade, a simplicidade, a realidade daquela época, sem tôdo entusiasmo sentimental. Essas poesias mostraram a psique dos homens e seu barômetro das almas, poesias que assinalaram e apresentaram Kästner na tradição da grande lírica alemã.

Duas antologias dêsses quatro volumes de lírica, Kästner publicou-as após 1933: "Doktor Erich Kästners lyrische Hausapotheke" (A farmácia doméstica lírica do Doutor Kästner) para o uso no estrangeiro, e "Bei Durchsicht meiner Bücher" (Com a revisão de meus livros) no ano de 1946, na Alemanha. O primeiro contém estrofes para terapêutica e para a vida privada, para a crise do sentimento humano como consôlo. O segundo une poemas politicos, antimilitares, sociais, satírico-sociais do tempo anterior ao govêrno dos naciona's-socialistas.

Com o volume de epigramas "Kurz und bündig" (Breve e conciso), tem êle a intenção de acordar a epigramática para uma vida nova, indicando rumos novos. Com os seus epigramas quer favorecer a influência para a educação e gôsto, entendimento e razão, arte e linguagem. Sua clareza e impregnância na linguagem é própria para o epigrama, para 
esta mais curta espécie poética. A coleção de Kästner contém aforismos de nossa época, bem formulados e pensados, sátiras corajosas e ataques contra o espírito atual.

Documentos d̀a criação poética de Kästner, nos anos de 1945 a 1952 são os livros "Der tägliche Kram" (As azáfamas diárias) e "Die kleine Freiheit" (A pequena liberdade), documentações comoventes do tempo confuso após a catástrofe alemã. Entrelaça-se o trágico com o humorístico, assestam-se ataques contra a estupidez e a ignorância, ridicularizando com humor benéfico de modo que sorrimos quando relembramos aquêles dias tristes ou nos quais dispensamos sorriso. A grande liberdade transtornou-se em pequena, e ambas incluem as lidas de cada dia.

Em 1955 Kästner publicou "Die 13 Monate" (Os 13 meses). Trata-se de um ciclo de poesias mensais, ilustrado por Richard Seewald. Nelas manifesta-se o fino tacto do lírico, sem acento satírico, o bom observador da natureza, dos homens no seu trabalho, um outro Kästner, para quem a poesia, primeiramente e finalmente, a realização criadora de imagens e símbolos através da língua.

Nas obras mencionadas está concentrada a criação lírica dêsse poeta humorístico, uma criação quantitativamente nã s enorme. Este fato talvez dependesse do nosso tempo, privado de humor, e depende ainda, no que as preocupações e penas sofidias com as coisas quotidianas impediram a entrada ao dispensador franco sorriso, ao humor.

O lírico nascido para presentear humor, voltando-se para o passado, vê sua obra abundante no ramo dos ensaios, panfletos e romances recreativos. Durante a carência involuntária, Kästner escreveu, para divulgação no estrangeiro, contos penetrados de humor profundo insuperável: "Drei Männer im Schnee" (Três homens na neve, 1934), "Die verschwundene Miniatur" (A miniatura desaparecida, 1936), e "Der kleine Grenzverkehr oder Georg und die Zwischenfälle" (O pequeno trânsito pela fronteira ou Jorge e os acidentes, 1938). São livros - afastados da política e da guerra - que divertem, 
oferecem prazer, fazem esquecer "den grauen Riesen de? Alltags" pelos conflitos dramáticos e delícias agradáveis a nossa alma. Mostram, também, que vale a pena viver a vida - neste globo terrestre infecto, se acreditarmos na humanidade verdadeira, decência, amor ao próximo e amizade. Com sucesso, tradutores e o cinema apoderam-se dêsse material grato, lançando ao mundo distante o nome de Kästner como escritor e autor. No periodo entre as duas guerras mundiais, Kästner publicou o seu único romance satírico da época: "Fabian - die Geschichte eines Moralisten" (Fabian - a história de um moralista). O título do mesmo era "Der Gang vor die Hunde" (O caminho para miséria). Concentrou Kästner nesta obra os motivos de volumes de poesia prèviamente editados e refinou a sùa ideologia. Fabian é um dos grandes romances de Berlim. Contém traços fortemente autobiográficos. Kästner conta os últimos dias de vida de um moço desempregado, que reconhece a irracionalidade da sua exictência, num mundo falsificado com suas instituiçöes mais absurdas ainda. A consciência indica-lhe o caminho do bem, o auxilio ao próximo. Dotado dêste forte desejo de pratica* o bem, joga-se êle num rio, apesar de não saber nadar, para salvar um rapazinho. Fabian morre afogado, e o rapazinho, contudo, chega a alcançar, chorando, a margem salvadora dio rio. O ceticismo afetuosamente amargurado para o poeta não é um intento final. Os aspectos dêle são afirmativos com esperança e alegria para o futuro. Quer reavivar os grandes valores espirituais do passado e as exigências dos grandes varões de todos os tempos e melhorá-los, quer revolucionar as opiniões e ideologias empoeiradas, em repor os ideais antigos em seus devidos lugares. A maior ousadia não é suficientemente forte para a desmobilização de uma moral antiquada. Podemos avaliar o "Fabian" como a obra maior e mais profunda do autor. Enquanto não cessar o brado pela humanidade nos homens, na espécie humana, êste livro há de ter o seu valor atual.

Obras artísticas são os livros juvenis e os infantis de 
Kästrier. Neste ramo, êle é um guia, um autor internacionaimente reconhecido. Seu amor às crianças e aos adolezcents:; a confiança no que é bom nêles, a infalível convicção do que é possivel torná-los corretos, dando-ines exemplos e ideais necessários, amadureceram e floresceram nos tomances escritos para êles, seus protegidos. Com delicado sentimento de adaptação e compreensão da psique infantil, escreveu essas narrações, não como vigília-adolescente, que, com o dedo indicador elevado, distribui conselhos do "Colégio bom", mas sob o ponto de vista de um pedagogo decidido, que não sòmente vê na criança uma forma prévia do ser adolescente, porém muito mais, trata-a com igual a si e reconhece assim, sem mesmo ter descido ao estado infantil ou ter-se degradado à tradicional posição de tia contadora de histórias infantis. Os assuntos êle os apanha do mundo infantil hodierno, revestindo-os com traje moderno de romance psicológico, social, ou de história criminal, que é a forma externa. Ao conteúdo fornece uma exposição de tema prevalente sempre para um temperamento infantil. Com ternura surpreendente, admirável num solteirão sem filho, descreve. 0 tênue coração humano, os laços entre pais e filhos, ent $\Xi$ crianças, entre amigos, o fluxo e refluxo dos sentimentos entr. alegria e tristeza, agitação e sossêgo. Dar um relato do conteúdo dessas narrativas não é necessário, porque não importa o quê de um generoso na vida, mas o como da configuração literária. E um como outro é plena bondade, não só em sentido caritativo ou moral, porém - como se tratasse de um bom trago em contraste em mau - maduro, nobre, perfeito. As boas qualidades dos seus "pequenos heróis", seus receios, sensações, também a vivacidade, êle as torna objetivas, conceptíveis, palpáveis. A abundância de pequenos episódios e dos mínimos escolhidos de uma virtude equivalente, testemunham um espírito agudo de observação e do conhecimento da alma infantil. Através da pureza e frescura dos livros encontra-se a firmeza da fé no inalterável e intangível, na nobreza da criança e a orientação no caminho da vida pelos grandes exemplos, quais êle, dêste modo, quer dar ao mundo 
infantil. Seus livros lêem-se fàcilmente, porque são reais, legitimos, cativantes, sensatos, e escritos com uma simpiicidade mais modesta. Na realidade, êles recompensam. Depois da leitura conhece-se mais da vida juvenil; muitos $j$ ja olvidaram os anos da infância, o intimo, suas delícias, às vezes mágoas e aflições. Aí não só fala um filósofo, senão ainda um conhecedor da vida. A obra em favor das crianças, ao solteiro Kästner, parece-lhe obrigação, que passa também ao leitor adulto, envolve-o formalmente, eleva-o acima do trivial, comum, indigno e baixo. A fascinação da arte prosáica não or namentada do poeta desenvolve-se no ambiente do lar paterno - freqüentemente pobre, mas feliz -, no alegre folgar das crianças lá no patio escolar, nas férias como na escola, as relações recíprocas da criança aos pais, planejando tolices, sonhando com o belo distante, com a felicidade, em camaradagem e na consciência da responsabilidade. Tudo é tão maravilhoso, suave, brando, e simultâneamente mesclado com rudeza, humor e esperteza tão naturais, que se dissolve em prazer: os pais acham um ao outro, a justiça é recompensada. o fraco consegue proteção e auxílio, confiança em si mesmo, o mal é punido, e o grande ou pequeno malfeitor dirige-se ao caminho do arrependimento, da emenda e da justiça. Amor ao próximo, decência e filantropia com as crianças levam muitas vêzes o triunfo do mundo dos adultos.

As obras principais de Kästner na parte infantil são: "Emil und die Detektive" (Emílio e os detetives), "Pünktchen und Anton" (Pontinho e Antāo), "Der 35. Mai" (O 35 de Maio). "Das fliegende Klassenzimmer" (A sala de aula voadora), "Emil und die drei Zwillinge" (Emílio e os três gêmeos), "Das doppelte Lottchen" (As duas Lolotas).

Com êsses romances Kästner criou algo inteiramente novo: sentimental e tenro, introduz seus pequenos leitores à vida prática; deixa-os perceber como a vida realmente é, prepara-os à severidade, trazida pela vida entre sêres humanos. Hermann Kesten diz anotando os livros infantis de Kästner: "Não li como criança literatura infantil, mas comecei direta- 
mente com a Bíblia, Schiller e Shakespeare. Só como adulto, ocasionalmente, tenho lido livros infantis, por exemplo, aquêle magnífico e espantoso livro de Swift "As viagens de Gulliver", ou os contos de fada, cheios de maravilhas e cobiça, dos Irmãos Grimm, uma série de livros que não foram destinados às crianças e foram apresentados a estas, na maioria dos casos, purificados e cândidos, numa forma mutilada e recortada ad usum delphini. Li como adulto também os livros infantis de Kästner, começando com "Emílio e os detetives" e terminando com "A conferência dos animais". Não posso dize: de experiência própria, como qualifica uma criança que entretanto passou esta idade, o Kästner, como mestre-escola. Parece-me que os meninos alemães nunca deveriam encontrar um mestre pior do que êste Kästner, que escreveu, depois de ter-se revelado satírico: Os Satíricos são Moralistas."

$\mathrm{Da}$ autoria de Kästner para gáudio da criançada procedem além disso as histórias admiràvelmente bem contadas, com ilustrações excelentes por Walter Trier: "Till Eulensp:egel", "Die Konferenz der Tiere" (A conferência dos animais), "Münchhausen" e "Der gestiefelte Kater" (O gato de botas). Em versos infantis temos: "Arthur mit dem langen Arm" (Artur de braço comprido), e "Das verhexte Telefon" (O telefone enfeitiçado).

Quase todos os livros de Kästner e, especialmente, os infantis, foram traduzidos para o inglês, francês, italiano, espanhol, português, holandês, norueguês, sueco, finlandês, polonês, tcheco, croático, búlgaro, esloveno, hebraico, japonês, e africano. Alguns foram impressos também para os cegos. Quase não existe um país do mundo que não adquirisse um livro de Kästner para traduzi-lo. Até das suas poesias, difíceis de serem traduzidas, existe uma versão em japonês. Nos seguintes países apareceram edições escolares e antologias das obras de Kästner: Inglaterra, França, América, Holanda, Suécia, Noruega. A linguagem clara e distinta de Kästner foi reconhecida como apta, de maneira especial, para a aprendizagem do idioma alemão nas escolas. Após a última guerra, 
no Japão, saíram oito livros em língua dêste país, e todos foram transmitidos pelas emissoras nacionais japonêsas, sucessivamente.

Já no ano de 1930 baseado na obra "Emílio e os detetives" produziram na Alemanha um filme. Kästner fêz os próprios scripts para esta filmagem, assim como para os filmes "Münchhausen", "Der kleine Grenzverkehr", "Das doppelte Lottchei1", "Pünktchen und Anton" e "Drei Männer im Schnee". O filme "Das doppelte Lottchen" (1950) foi premiado e distinguido com a primeira e suprema medalha do cinema alemão. Sôbre a película "Drei Männer im Schnee", que percorreu 1955 os palcos de Berlim, um jornal dessa capital comentou: "Alegria ilimitada e muitíssimo prazer no diálogo atraente e engraçado ofereceu a Áustria com o filme "Drei Männer im Schnee" para o $5 .^{\circ}$ festival berlinense de cinema..."

Com a obra "Die Schule der Diktatoren" (A escola de ditadores) Kästner demonstrou seu talento como dramaturgo. Essa comédia é uma sátira contra a ditadura e contra o "Führerprinzip".

Erich Kästner é hoje em dia na República Federal da Alemanha o autor mais filmado. Não só o cinema, porém também o rádio e o teatro, difundiram muitas novelas baseadas nas suas obras, e, nos palcos, peças teatrais.

Essa é a obra literária do poeta e prosador que conta hoje 58 aos de idade. Não é muita coisa, de fato, para chamá-lo quantitativamente um escritor fecundo, porém, qualitativamente, as produções da sua "pequena fábrica de versos" como êle mesmo chama - possuem um valor internacionalmente reconhecido. 